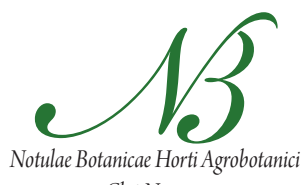

Cluj-Napoca

\title{
Salinity Tolerance of the Hygrophilous Plant Species in the Wetlands of the South of the Iberian Peninsula
}

\author{
Francisco GÓMEZ MERCADO ${ }^{1 *}$, Fernando DEL MORAL TORRES² \\ Esther GIMÉNEZ LUQUE', Sergio DE HARO LOZANO² \\ ${ }^{1}$ Universidad de Almeria. Campus de Excelencia Internacional Agroalimentario, CEIA3, Dpto. de Biología Vegetal \\ y Ecologia, Ctra. Sacramento s/n, E-04120 Almería,Spain; frgomez@ual.es (*orresponding author) \\ ${ }^{2}$ Universidad de Almería. Campus de Excelencia Internacional Agroalimentario, CEIA3, Dpto. de \\ Edafología y Quimica Agricola, Ctra. Sacramento s/n, E-04120 Almería, Spain
}

\begin{abstract}
The aim of this work is to evaluate with the salinity tolerance of the hygrophilous plant species recorded along the River Guadiamar (SW of the Iberian Peninsula) and in four sublittoral wetlands of the bay of Almería (SE of the Iberian Peninsula). The first of these wetlands is an Atlantic-type open wetland. The other four wetlands in Almería are closed lagoon-like wetlands. The data of each species are given and grouped in categories defined by tolerance range. The results obtained for the species found in the two sites are then compared. The salinity conditions of the soils of these two types of wetlands are also compared to discover any possible cause for differentiation. Finally, the different units of measurement of salinity available and some conversion models for them will be discussed. As a result of the present data and analysis, the study proposes a model to estimate total dissolved salts from electrical conductivity.
\end{abstract}

Keywords: halophytes, marshlands, saline soils, salinity, salt marshes, salt tolerance.

\section{Introduction}

Under natural conditions of growth and development, plants are inevitably exposed to different types of stresses, such as drought, salinity, low and high temperatures, flooding and high radiation (Hessini et al., 2009). Salt stress inhibits plant growth by disrupting ion and water homeostasis as well as causing oxidative stress (Cant et al., 2007). The extent of growth and yield reduction due to salt stress depends on the species, duration and severity of the salt stress.

Saline conditions reduce the ability of plants to absorb water, causing rapid reductions in growth rate, and induce many metabolic changes similar to those caused by water stress (Epstein 1980). Halophytes are plants able to complete their life cycle in a substrate rich in $\mathrm{NaCl}$ (Schimper, 1891). One of the most important properties of halophytes is their salinity tolerance (Lieth, 1999). For obligate halophytes this substrate offers advantages for competition with salt sensitive plants (glycophytes). There is a wide range of tolerance among the 2600 known halophytes (Amzallag, 1994; Lieth and Menzel, 1999; Pasternak, 1990). However, information about these halophytes needs careful partial checking (Koyro et al., 2009).

A precondition for sustainable utilization of suitable halophytes is precise knowledge about their salinity tolerance and the various mechanisms enabling a plant to grow in (their natural) saline habitats (Ashraf, 1994; Greenway and Munns, 1980; Koyro et al., 1997; Marcum, 1999; Warne et al., 1999; Weber and D'Antonio, 1999; Winter et al., 1999).

The impact of salinity on plants has been extensively dealt with in scientific literature, in particular as regards toxicity (Mateos Naranjo et al., 2011; Parida and Das, 2005), adaptations (Koyro et al., 2009; Weber, 2009), nutritional problems (Castagna et al., 2009; Flowers, 2004; Martínez-Ballesta et al., 2004), germination (e.g., Ahmed and Khan, 2010; Guma et al., 2010; Li, 2008; Orlovsky et al., 2011; Redondo Gómez et al., 2011; Vicente et al., 2009), biodiversity (El Shaer, 2009), etc. However, there are not many studies on the salinity tolerance of wild plants. In this sense, it must mention the work of Álvarez Rogel et al. (2001, 2006, 2007) Pujol et al. (2000) and Redondo Gómez et al. (2004, 2007, 2008, 2010).

The aim of this study has been three-fold: firstly, to determine the salinity tolerance ranges for the hygrophilous plants growing in the wetlands of the south of the Iberian Peninsula; secondly, to compare the salinity conditions of an Atlantic wetland (open marshland) and a Mediterranean wetland (closed salt marsh); thirdly, to provide data for the conversion of salinity measurements into weight/ volume percentage $(\% \mathrm{w} / \mathrm{v})$, total dissolved salts (TDS $\left.\mathrm{g} \cdot \mathrm{L}^{-1}\right)$ and electrical conductivity $\left(\mathrm{EC} \mathrm{d} S \cdot \mathrm{m}^{-1}\right)$. 
Material and methods

\section{Study area}

In this paper results obtained in the area of the River Guadiamar and four littoral wetlands of the bay of Almería (Fig. 1) located in the south of the Iberian Peninsula in the Mediterranean region are shown.

The Guadiamar River is located in the Corredor Verde del Guadiamar, a narrow strip of land about $100 \mathrm{~km}$ long and 7900 ha in area connecting the natural parks of Aracena and Picos de Aroche and the Sierra Norte of Seville with the marshlands of the River Guadalquivir (Donnana National Park) where it flows into the Atlantic Ocean. In its upper reaches the river runs over metamorphic materials belonging biogeographically to the Lusitan-Extremadurean Province (Marianic-Monchiquensean Sector) (Rivas Martínez et al., 1997). In its middle reaches the soils are marly-sandy materials of the Betic Province (Hispalensean Sector) and in the lower reaches the terrain adopts the form of a typically marsh-like, mud-clay plain in the GaditanOnubensean-Algarvian Province (Gaditan-Onubensean Sector). The bioclimate (Rivas Martínez and Loidi, 1999) is Mediterranean, pluviseasonal-oceanic with two thermotypes, namely, thermomediterranean and mesomediterranean, and two ombrotypes: dry and subhumid.

The wetlands under study in the bay of Almería (Mediterranean coast) are the following: Charcones de Punta
Entinas (131 ha), Salinas de Cerrillos (480 ha), Salinas del Cabo de Gata (312 ha) and Desembocadura de la Rambla Morales (6 ha). These are more or less closed sublittoral wetlands of brackish, salty water coming from the water table or from the sea. The Salinas de Cabo de Gata are still worked for the production of salt and receive a regular supply of sea water. The Salinas de Cerrillos have not been worked since 1988. In biogeographical terms, these sites are located in the Murcian-Almeriensian Province (Almeriensian Sector) and in bioclimatic terms they have a desert-like oceanic bioclimate with a lower thermomediterranean thermotype and a lower semiarid ombrotype.

\section{Data collection and plant species}

To study the behaviour of the plant species recorded in the River Guadiamar (Tab. 1) it was selected 28 plots located along the course of the river. In each of these plots it has been made a relevé of the species present and took a soil sample to estimate $\mathrm{EC}$ and $\mathrm{Na}^{+}$content of the saturation extract. In the wetlands of the bay of Almería first has been draw a grid of 63 sampling plots in the form of $4 \times 4$ $\mathrm{m}$ squares $\left(16 \mathrm{~m}^{2}\right)$ arranged as transects perpendicular to the banks of the lagoons. The distance between plots and the number of plots per transect ( 2 to 4 ) was determined by the vegetation profile. In order to take into account the seasonal fluctuations of the variables under study (EC, $\mathrm{Na}^{+}$and TDS), each of the plots was sampled every three
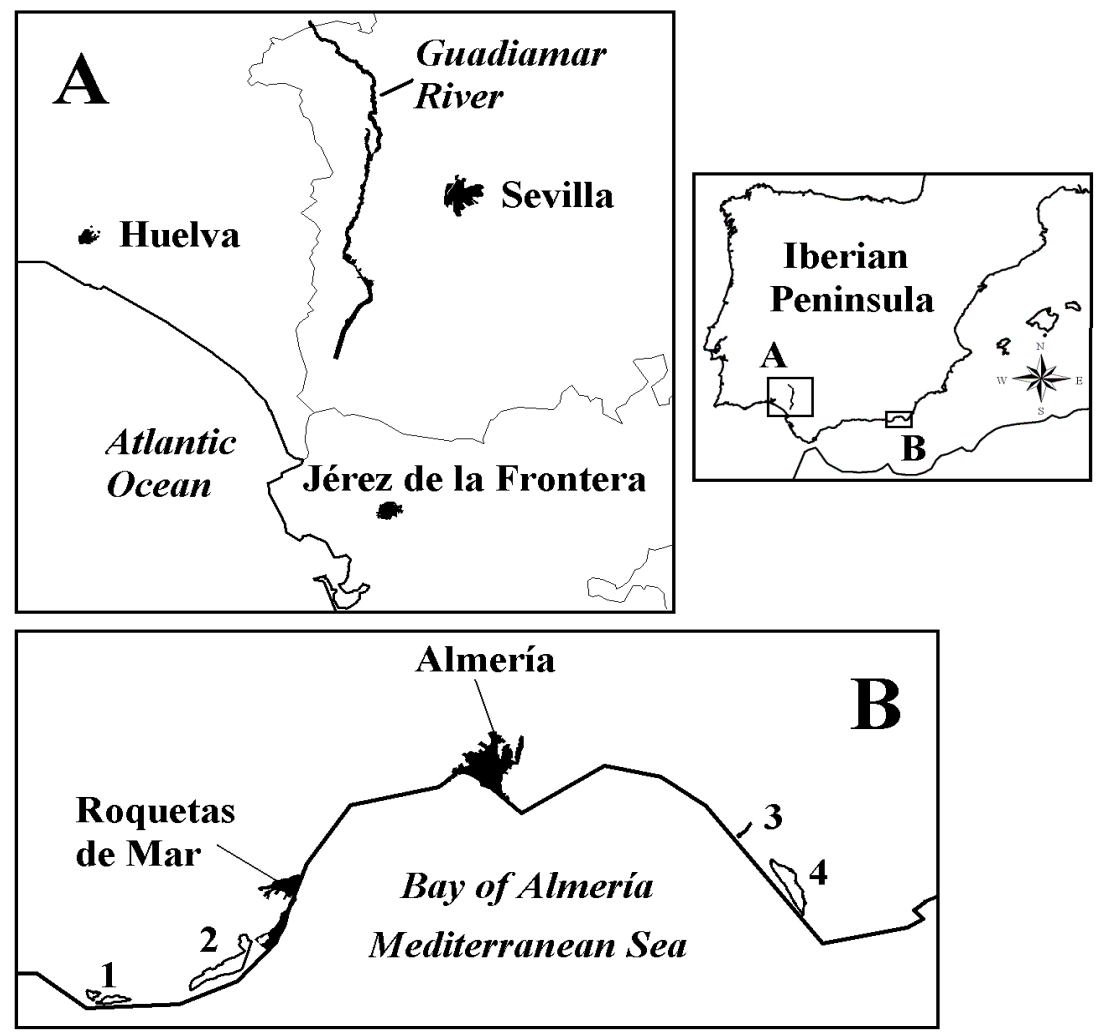

Fig. 1. Location of the study area. A: River Guadiamar. B: Bay of Almería. 1 Charcones de Punta Entinas. 2 Salinas de Cerrillos. 3 Desembocadura de la Rambla Morales. 4 Salinas de Cabo de Gata 
20

months for two years (8 replications). It has been also estimated the vegetation cover rate and the species present (Tab. 1).

The soil sample was made up of five subsamples uniformly distributed in the area under study and reached a final volume equivalent to $3 \mathrm{dm}^{3}$. Soil samples were taken at a depth of $30 \mathrm{~cm}$, whatever the existing horizon sequence (Díaz-Maroto and Vila-Lameiro, 2008; Hagen-Thorn et al., 2004). Soil samples were sieved through a $2 \mathrm{~mm}$ screen after removing any plant materials and roots. Electrical conductivity in soil saturation extracts (Rhoades, 1996) was measured by means of a Crison conductimeter 522 . $\mathrm{Ca}^{++}$and $\mathrm{Mg}^{++}$were determined by absorption spectrophotometry (Perkin Elmer AA400), $\mathrm{Na}^{+}$and $\mathrm{K}^{+}$by flame photometry (Jenway PFP7). $\mathrm{Cl}^{-}, \mathrm{NO}_{3}{ }^{-}$and $\mathrm{SO}_{4}{ }^{=}$by ionic chromatography (Dionex ICS1000) using a $\mathrm{HCO}_{3} / \mathrm{CO}_{3}$ buffer as the mobile phase. $\mathrm{HCO}_{3}^{-}$was measured by titration. The data obtained in this manner was used as a base to estimate total dissolved salts and, except for the $\mathrm{Na}^{+}$ content, are not shown in this paper.

\section{Data analysis methods}

The minimum, average and maximum values for each of the variables concerned were estimated using the ana- lytical results obtained from the samples taken in the plots where each of the plant species under study was recorded. Of the 504 EC-TDS data obtained, as experimental results, from the samples taken in the wetlands of the bay of Almería, $402(80 \%)$ were used to adjust the regression models and $102(20 \%)$ to validate these models. A linear regression model, without including the constant, for all the data and the partial models for the different conductivity ranges were proposed. In this last case, the same proportion of data for the calculation of the models as for their validation was maintained.

\section{Results and discussion}

Ranges of salinity tolerance of the hygrophilous species

Salinity refers to the presence in the soil of salts whose solubility is equal to or higher than that of gypsum (2.4 g. $\left.L^{-1}\right)$. The most common salts are: $\mathrm{NaCl}, \mathrm{MgCl}_{2}, \mathrm{Na}_{2} \mathrm{SO}_{4}$ $\mathrm{CaSO}_{4}, \mathrm{MgSO}_{4}, \mathrm{Ca}\left(\mathrm{HCO}_{3}\right)_{2}$ and $\mathrm{Mg}\left(\mathrm{HCO}_{3}\right)_{2} \cdot \mathrm{Na}_{2} \mathrm{CO}_{3}$ and $\mathrm{NaHCO}_{3}$ are relatively rare but have a great impact on alcalinity. Salts that are not very soluble $\left(\mathrm{CaCO}_{3}, \mathrm{MgCO}_{3}\right.$ and even $\mathrm{CaSO}_{4}$ ) precipitate before reaching harmful levels for plants.

Tab. 1. Species studied along the River Guadiamar and in the bay of Almería with full names and number of samples $(\mathrm{N})$ for each one

\begin{tabular}{|c|c|c|c|}
\hline \multicolumn{2}{|l|}{ River Guadiamar } & \multicolumn{2}{|l|}{ Bay of Almería } \\
\hline Species & $\mathrm{N}$ & Species & $\mathrm{N}$ \\
\hline Alnus glutinosa (L.) Gaertner & 1 & Arthrocnemum macrostachyum (Moric.) Moris & 240 \\
\hline Arthrocnemum macrostachyum (Moric.) Moris & 7 & Asparagus horridus $\mathrm{L}$. & 8 \\
\hline Flueggea tinctoria (L.) G.L. Webster & 4 & Asteriscus maritimus (L.) Less. & 8 \\
\hline Fraxinus angustifolia Vahl & 7 & Atriplex halimus L. & 16 \\
\hline Juncus acutus L. & 3 & Cynanchum acutum $\mathrm{L}$. & 8 \\
\hline Nerium oleander L. & 5 & Frankenia corymbosa Desf. & 128 \\
\hline Phragmites australis (Cav.) Trin. ex Steud. & 5 & Halimione portulacoides (L.) Aellen & 56 \\
\hline Populus alba L. & 4 & Inula critmoides $\mathrm{L}$. & 112 \\
\hline Salix salviifolia Brot. & 1 & Juncus acutus L. & 64 \\
\hline Sarcocornia fruticosa & 8 & Juncus maritimus Lam. & 88 \\
\hline Scirpus maritimus subsp. compactus Hoffm. & 11 & Juncus subulatus Forskäl & 8 \\
\hline Spartina densiflora Brongn. & 5 & Limonium cossonianum Kuntze & 56 \\
\hline Suaeda vera Forssk. ex J.F. Gmel. & 2 & Limonium delicatulum (Girard) Kuntze & 128 \\
\hline Tamarix africana Poir. & 1 & Lycium intricatum Boiss. & 72 \\
\hline Tamarix mascatensis Bunge & 1 & Phragmites australis (Cav.) Trin. ex Steud. & 104 \\
\hline \multirow[t]{10}{*}{ Ulmus minor Mill. } & 3 & Salicornia ramosissima J. Woods & 8 \\
\hline & & Salsola vermiculata $\mathrm{L}$. & 8 \\
\hline & & Sarcocornia fruticosa (L.) A. J. Scott & 104 \\
\hline & & Sarcocornia perennis subsp. alpini (Lag.) Castrov. & 256 \\
\hline & & Sporobolus pungens (Schreb.) Kunth & 32 \\
\hline & & Suaeda vera Forssk. ex J.F. Gmel. & 96 \\
\hline & & Tamarix boveana Bunge & 8 \\
\hline & & Tamarix gallica $\mathrm{L}$. & 8 \\
\hline & & Tamarix canariensis Willd. & 88 \\
\hline & & Typha domingensis Pers. & 8 \\
\hline
\end{tabular}




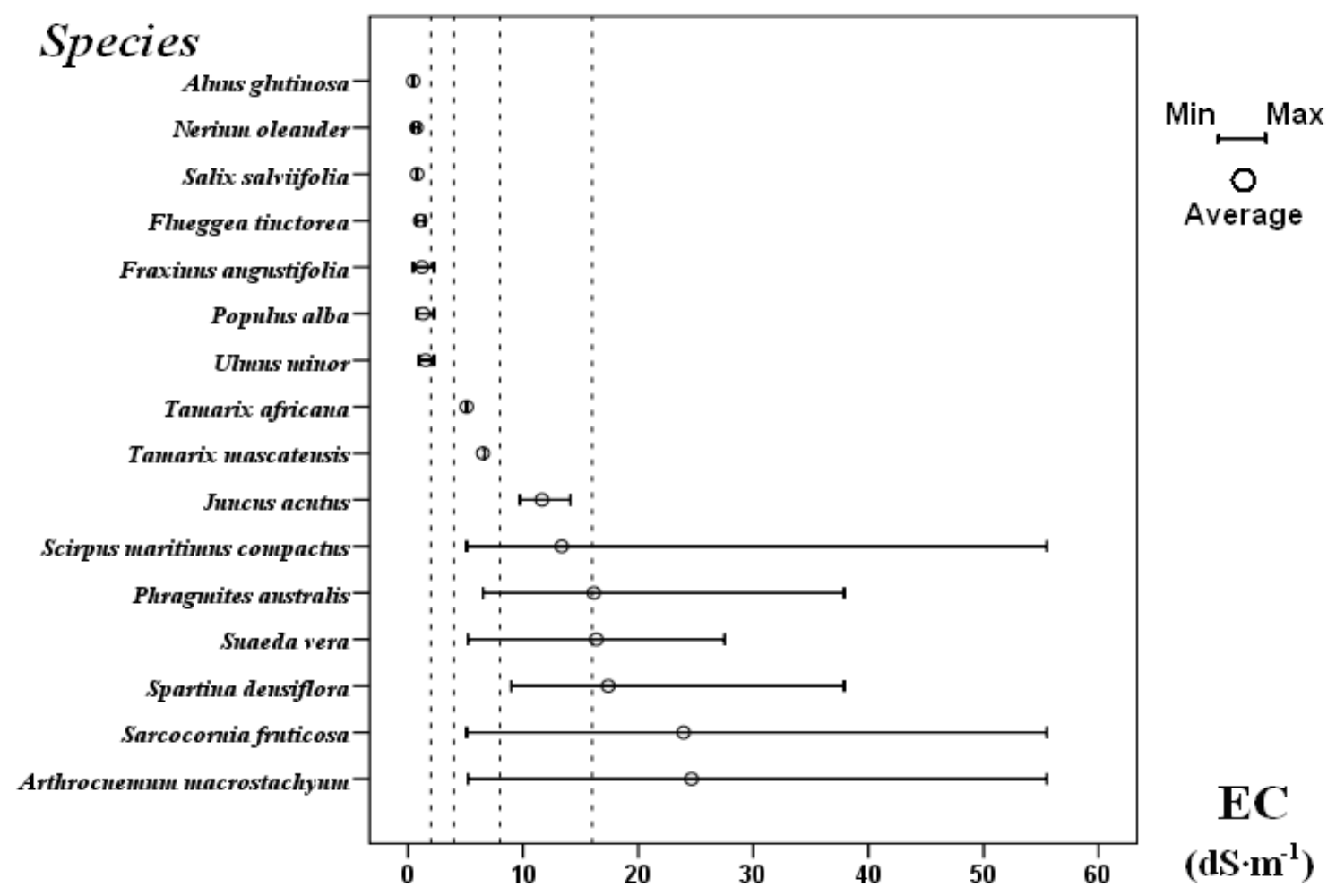

Fig. 2. Ranges of tolerance to electrical conductivity recorded for 16 species along the River Guadiamar. Vertical dotted lines show the EC intervals in saturation extracts proposed by Abrol et al. (1988) to evaluate saline conditions: 0-2 $\mathrm{d} S \cdot \mathrm{m}^{-1} \ll$ non saline $\gg ; 2-4 \mathrm{dS} \cdot \mathrm{m}^{-1} \ll$ slightly saline $\gg ; 4-8 \mathrm{dS} \cdot \mathrm{m}^{-1} \ll$ moderately saline $» ; 8-16 \mathrm{dS} \cdot \mathrm{m}^{-1} \ll$ strongly saline ; $>16 \mathrm{dS} \cdot \mathrm{m}^{-1}$ «very strongly saline»

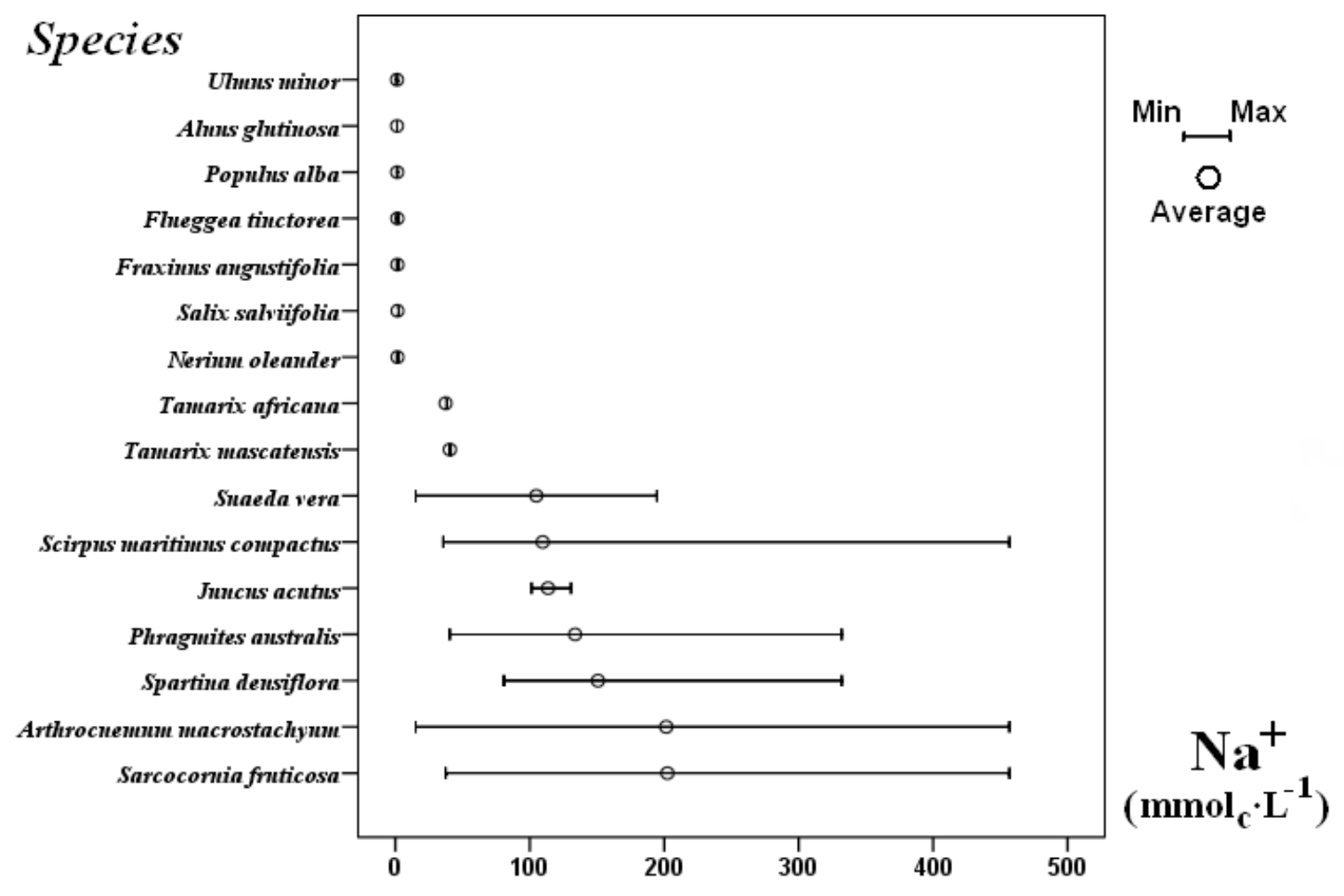

Fig. 3. Ranges of tolerance to $\mathrm{Na}^{+}$recorded for 16 species along the River Guadiamar 
22

Along the course of the River Guadiamar it was found a succession of hygrophilous species which replace one another, among other reasons, by virtue of their salinity tolerance. At the river headwaters (Lusitan-Extremadurean territory) species such as Alnus glutinosa, Nerium oleander, Salix salviifolia or Flueggea tinctoria are found. These species belong to the «non saline» interval $\left(0-2 \mathrm{dS} \cdot \mathrm{m}^{-1}\right)$ (Fig. 2 ), as defined in the arrangement proposed by Abrol et al. (1988), which sorts salinity records by the electrical conductivity of the saturation extract. The $\mathrm{Na}^{+}$content of the saturation extract of these soils is below $2.3 \mathrm{mmol} \cdot \mathrm{L}^{-1}$ in all cases (Fig. 3). In both cases the ranges are very narrow. In the middle reaches of the river (Hispalensean territory) these species are replaced by others which, in some cases, co-occurred in the upper reaches of the river. According to the salinity tolerance of these species they can be described as «slightly saline» $\left(2-4 \mathrm{dS} \cdot \mathrm{m}^{-1}\right)$, with maximum values just over $2 \mathrm{dS} \cdot \mathrm{m}^{-1}$. This is the case of Fraxinus angustifolia, Populus alba and Ulmus minor. Their $\mathrm{Na}^{+}$content is extremely low and similar to the previously mentioned species. In the lower reaches of the Hispalensean territory, where conditions already indicate a transition towards areas influenced only to a small degree by the tidal flow, it was found species such as Tamarix africana and T. mascatensis, which tolerate «moderately saline» conditions, between 4 and $8 \mathrm{dS} \cdot \mathrm{m}^{-1}$. Here the $\mathrm{Na}^{+}$content reaches values close to $50 \mathrm{mmol} \cdot \mathrm{L}^{-1}$. When the tidal influence is very strong (lower reaches of the river, in the Gaditan-Onubensean territory), species such as Juncus acutus and Scirpus maritimus subsp. compactus appear. The average salinity values of these species fall within the «strongly saline» interval $\left(8-16 \mathrm{dS} \cdot \mathrm{m}^{-1}\right)$, although the maximum value of $S$. maritimus subsp. compactus is above $55 \mathrm{dS} \cdot \mathrm{m}^{-1}$. The average $\mathrm{Na}^{+}$ content of these species is over $100 \mathrm{mmol} \cdot \mathrm{L}^{-1}$, and $S$. maritimus reaches $450 \mathrm{mmol} \cdot \mathrm{L}^{-1}$. Consequently, these species can be considered as typically marsh-loving plants. Phragmites australis, Suaeda vera, Spartina densiflora, Sarcocornia fruticosa and Arthrocnemum macrostachyum exhibit average EC values above $16 \mathrm{dS} \cdot \mathrm{m}^{-1}$ (i.e., within the «very strongly saline» interval) and wide tolerance ranges. The average $\mathrm{Na}^{+}$values are above $130 \mathrm{mmol} \cdot \mathrm{L}^{-1}$, with maximum values of $456.73 \mathrm{mmol} \cdot \mathrm{L}^{-1}$.

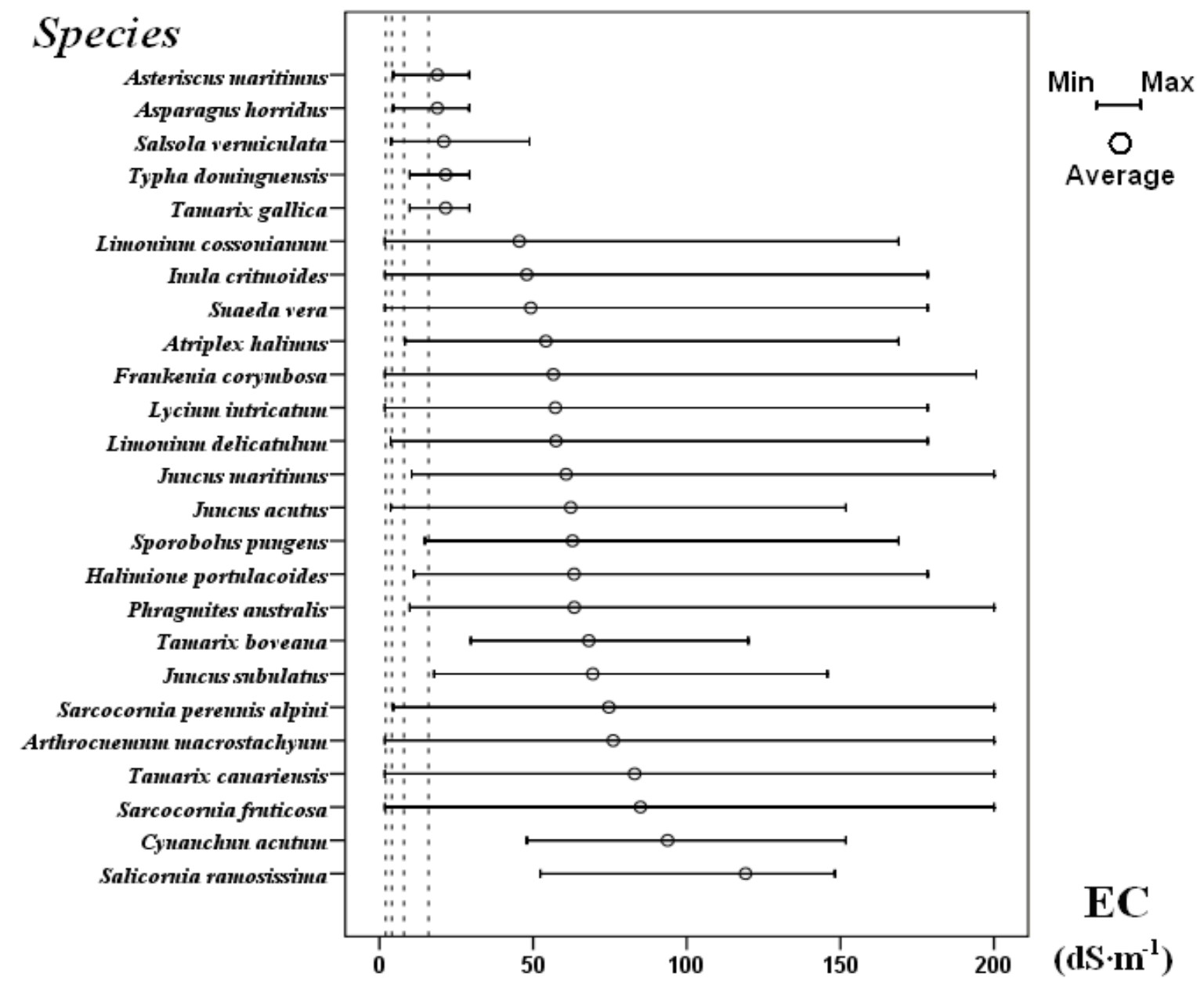

Fig. 4. Ranges of tolerance to EC for 25 species of the wetlands of the bay of Almería. Vertical dotted lines show the EC intervals in saturation extracts proposed by Abrol et al. (1988) to evaluate saline conditions: $0-2 \mathrm{dS} \cdot \mathrm{m}^{-1} \ll$ non saline $» ; 2-4 \mathrm{dS} \cdot \mathrm{m}^{-1} \ll$ slightly

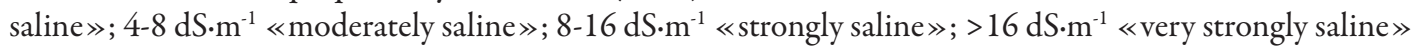


All the species found in the samples taken in the wetlands of the bay of Almería lie within the salinity interval of «very strongly saline», with average EC values over 16 dS. $\mathrm{m}^{-1}$ (Fig. 4).

Asteriscus maritimus (average EC $\left.=18.82 \mathrm{dS} \cdot \mathrm{m}^{-1}\right), A s$ paragus horridus (average $\left.\mathrm{EC}=18.82 \mathrm{dS} \cdot \mathrm{m}^{-1}\right)$, Salsola vermiculata (average $\mathrm{EC}=20.93 \mathrm{dS} \cdot \mathrm{m}^{-1}$ ), Typha dominguensis (average EC $=21.55 \mathrm{dS} \cdot \mathrm{m}^{-1}$ ) and Tamarix gallica (average $\left.\mathrm{EC}=21.55 \mathrm{dS} \cdot \mathrm{m}^{-1}\right)$ appear at the lowest end of this interval and exhibit narrow tolerance ranges. Their maximum values are close to $30 \mathrm{dS} \cdot \mathrm{m}^{-1}$ ( 48.8 in the case of Salsola vermiculata). They tend to grow either in the periphery of the lagoons, where sea water has little or no influence, or in places usually water-logged with less saline groundwater, as in the case of Typha dominguensis. $\mathrm{Na}^{+}$average contents in the saturation extract are about $150 \mathrm{mmol} \cdot \mathrm{L}^{-1}$, with maximum values close to $250 \mathrm{mmol} \cdot \mathrm{L}^{-1}$. Salsola vermiculata has an average value of 183.62 and a maximum value of $439.18 \mathrm{mmol} \cdot \mathrm{L}^{-1}$.

The rest of the species tolerate average $\mathrm{EC}$ values above $45 \mathrm{dS} \cdot \mathrm{m}^{-1}$ with Salicornia ramosissima reaching 119.15 $\mathrm{d} S \cdot \mathrm{m}^{-1}$. Tolerance ranges are extremely wide due to the strong fluctuations induced by the flooding-drying cycle of the lagoons. In most cases, maximum values are close to $200 \mathrm{dS} \cdot \mathrm{m}^{-1}$. A similar pattern is found for $\mathrm{Na}^{+}$and TDS. Average $\mathrm{Na}^{+}$values vary from 500 to $1500 \mathrm{mmol} \cdot \mathrm{L}^{-1}$ with maximum values as high as $4868.29 \mathrm{mmol} \cdot \mathrm{L}^{-1}$ in the case of Sarcocornia perennis subsp. alpini. Average TDS values range between 45 and $130 \mathrm{~g} \cdot \mathrm{L}^{-1}$ with an absolute maximum value of $368.71 \mathrm{~g} \cdot \mathrm{L}^{-1}$ corresponding again to $S$. alpini.

$\mathrm{NaCl}, \mathrm{MgCl}_{2}$ and $\mathrm{MgSO}_{4}$ are the predominant salts in sea water and $\mathrm{Na}_{2} \mathrm{SO}_{4}$ can occur as a result of the presence of the others. For this reason it is not surprising that they are also the most frequent salts in the soils. Many of the current problems concerning soil salinity derive, more or less directly, from the ancient presence of sea salts.

The first problem brought about by a high concentration of soluble salts is the excessive increase in the osmotic pressure (decrease in the osmotic potential), which prevents unadapted plants from absorbing water adequately.

Another fundamental problem is the result of the presence of alkalinized $\mathrm{Na}^{+}$(derived from $\mathrm{Na}_{2} \mathrm{CO}_{3}$ and $\mathrm{NaH}-$ $\mathrm{CO}_{3}$ ) in relatively high concentrations. It is the colloidal dispersion originated by this strong dispersing agent that destroys the soil structure with the ensuing decrease in soil permeability and aeration. This effect induces waterlogging, reducing conditions, reduced biological activity, root suffocation, etc. Consequently, it must distinguish between saline soils, which, strictly speaking, always show a high content of soluble salts (of these sodium salts are usually absent) and alkali soils, where, although they are not necessarily high in salt concentration, most salts are

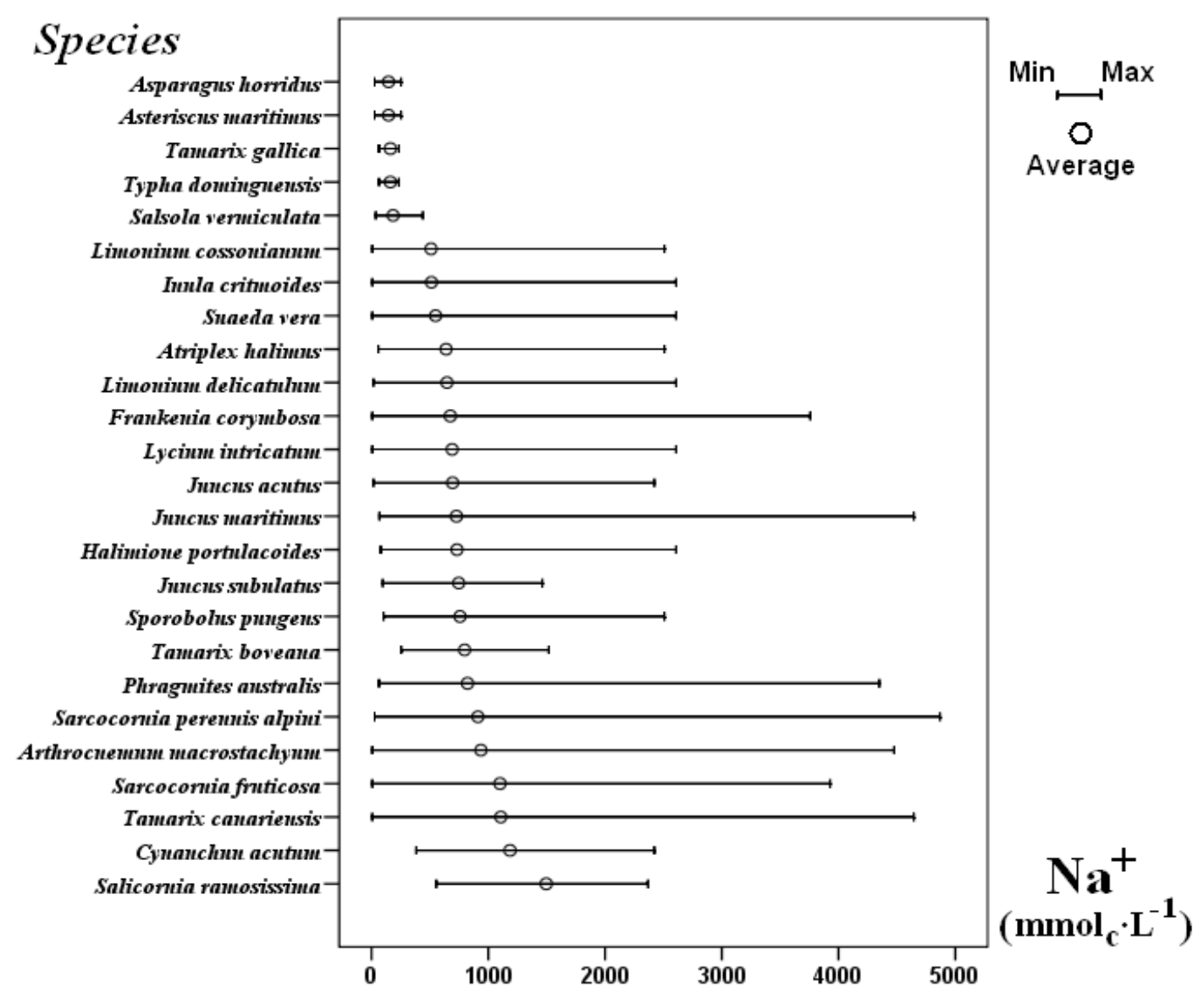

Fig. 5. Ranges of tolerance to $\mathrm{Na}^{+}$for 25 species of the wetlands of the bay of Almería 


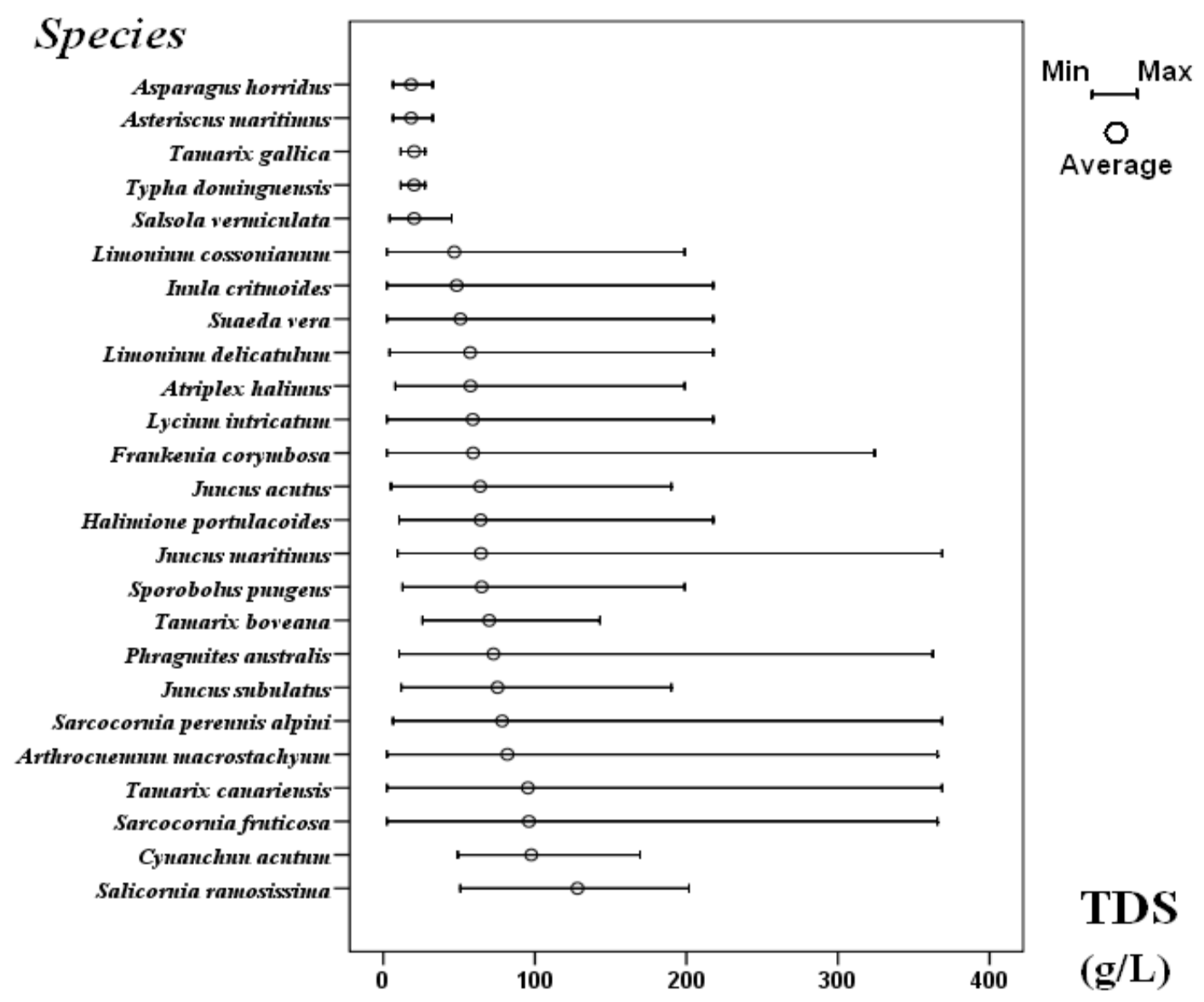

Fig. 6. Ranges of tolerance to TDS for 25 species of the wetlands of the bay of Almería

alkalizing. There are also saline-alkali soils with an in-between soil profile.

Although some authors consider that soil is saline when its total salt content is over $1 \%$, most researchers see the threshold at $1 \%$ content (Marañés et al., 1998), which is when many plants begin to be affected. A value of $4 \mathrm{dS} \cdot \mathrm{m}^{-1}$ for the electrical conductivity (EC) in the water extracted from a saturated paste at $25^{\circ} \mathrm{C}$ is usually accepted as the limit for a saline character (Abrol et al., 1988). Likewise, soil is usually regarded as alkaline (sodium soils) when the exchangeable sodium percentage (ESP), as compared to the total fixed cations, is equal to or higher than $15 \%$ (Abrol et al., 1988). This value corresponds to a sodium adsorption ratio $(\mathrm{SAR}) \approx 13$.

Along the River Guadiamar it was found a salinity gradient (increasing $\mathrm{EC}$ and $\mathrm{Na}^{+}$values) which shows that plant species are replaced according to their ability to endure such conditions. Consequently, this is an ideal scenario for the study of the limits of tolerance to salinity among the different groups of species. The most significant thresholds were the following:

a) $\mathrm{EC}<2 \mathrm{dS} \cdot \mathrm{m}^{-1} ; \mathrm{Na}^{+}<2.3 \mathrm{mmol} \cdot \mathrm{L}^{-1}$. Here it was found non halophilous species, such as Alnus glutinosa, Nerium oleander, Salix salviifolia or Flueggea tinctoria.

b) $2 \mathrm{dS} \cdot \mathrm{m}^{-1}<\mathrm{EC}<5 \mathrm{dS} \cdot \mathrm{m}^{-1}$; $\mathrm{Na}^{+}<2.3 \mathrm{mmol} \cdot \mathrm{L}^{-1}$. Here it was found non halophilous species, such as Fraxinus an- gustifolia, Populus alba and Ulmus minor, able to tolerate moderate salinity.

c) $\mathrm{EC}>5 \mathrm{dS} \cdot \mathrm{m}^{-1} ; \mathrm{Na}^{+}>2.3 \mathrm{mmol} \cdot \mathrm{L}^{-1}$. The previous species disappear and are replaced by typically halophilous taxa, such as Tamarix africana, T. mascatensis, Juncus acutus, Scirpus maritimus subsp. compactus, Phragmites australis, Suaeda vera, Spartina densiflora, Sarcocornia fruticosa and Arthrocnemum macrostachyum, which compete successfully under these conditions. In the Almeriensian wetlands, where the salinity values are, at least seasonally, much higher than those found along the River Guadiamar, it has been observed that some of these species tolerate much higher salinity. This is the case of Sarcocornia fruticosa, Arthrocnemum macrostachyum or Phragmites australis, which can survive with an EC of $200 \mathrm{dS} \cdot \mathrm{m}^{-1}, \mathrm{Na}^{+}$values close to $4500 \mathrm{mmol} \cdot \mathrm{L}^{-1}$ and TDS values over $365 \mathrm{~g} \cdot \mathrm{L}^{-1}$.

Comparative analysis of the salinity conditions of an Atlantic wetland and a Mediterranean wetland

Along the River Guadiamar it was took some samples with EC values varying from 0.46 to $55.50 \mathrm{dS} \cdot \mathrm{m}^{-1}$ and $\mathrm{Na}^{+}$ concentrations in the saturation extract between 0.79 and $456.73 \mathrm{mmol} \cdot \mathrm{L}^{-1}$. In the wetlands of the bay of Almería the EC values range from 1.74 to $200.00 \mathrm{dS} \cdot \mathrm{m}^{-1}$. $\mathrm{Na}^{+}$concentration varies from 5.95 to $4868.29 \mathrm{mmol} \cdot \mathrm{L}^{-1}$. The recorded TDS values lie between 2.46 and $368.71 \mathrm{~g} \cdot \mathrm{L}^{-1}$. 
Few species are found both along the River Guadiamar (Atlantic wetland) and in the wetlands of the bay of Almería (Mediterranean wetlands). These are always halophilous species which, in the case of the River Guadiamar, are restricted to the marshes in the lower reaches

\section{Conversion of salinity measurements}

As already suggested by many authors (Abrol et al., 1988; APHA, 1992), there is a close co-relation between the recorded EC values of the saturation extract and TDS (Tab. 2).

Tab. 2. Linear regression models, excluding interception, estimated for all the samples (general model) and for samples sorted by intervals. $\mathrm{N}$ indicates the number of samples used to adjust the model. TDS in $\mathrm{g} \cdot \mathrm{L}^{-1}$ and $\mathrm{EC}$ in $\mathrm{dS} \cdot \mathrm{m}^{-1}$

\begin{tabular}{|c|c|c|c|c|c|}
\hline & $\mathrm{N}$ & Model & $\mathrm{p}$ value & $\mathrm{R}^{2}$ & $\begin{array}{l}95 \% \text { Confidence } \\
\text { interval for slope }\end{array}$ \\
\hline General model & 402 & $\mathrm{TDS}=1.161 \cdot \mathrm{EC}$ & $<0.001$ & 0.938 & $1.132-1.190$ \\
\hline $0<\mathrm{EC}<100 \mathrm{dS} \cdot \mathrm{m}^{-1}$ & 279 & $\mathrm{TDS}=0.954 \cdot \mathrm{EC}$ & $<0.001$ & 0.967 & $0.934-0.975$ \\
\hline $100<\mathrm{EC}<175 \mathrm{dS} \cdot \mathrm{m}^{-1}$ & 100 & $\mathrm{TDS}=1.114 \cdot \mathrm{EC}$ & $<0.001$ & 0.972 & $1.077-1.152$ \\
\hline $\mathrm{EC}>175 \mathrm{dS} \cdot \mathrm{m}^{-1}$ & 23 & $\mathrm{TDS}=1.490 \cdot \mathrm{EC}$ & $<0.001$ & 0.954 & $1.345-1.635$ \\
\hline
\end{tabular}

of the river, especially Juncus acutus, Phragmites australis, Suaeda vera, Sarcornia fruticosa and Arthrocnemum macrostachyum. For all of them, the salinity values recorded in the Almeriensian wetlands are considerably higher than those in the marshlands of the River Guadiamar. These differences reveal the general conditions of both wetlands. The Atlantic marshlands are open ecosystems undergoing a regular fresh water supply and the ebb and flow of sea tides. By contrast, the Mediterranean lagoons (albuferas) are relatively closed systems with little fresh water supply and sea water flooding their salt marshes. In the very dry summer season, these lagoons are almost completely dried up through evaporation, which dramatically increases the salt concentration in the soil. Less soluble salts $\left(\mathrm{CaCO}_{3}\right.$, $\mathrm{MgCO}_{3}$ and $\mathrm{CaSO}_{4}$ ) precipitate and the soil solution is enriched with ions from the more soluble salts, such as $\mathrm{Na}^{+}$, $\mathrm{Cl}^{-}$or $\mathrm{SO}_{4}=$. The regular flooding and drying cycles keep supplying new salts to the soil with a progressive increase in the total concentration. In the Atlantic marshlands like those of the River Guadiamar, these flooding and drying cycles are very short as they are mainly affected by tidal influence and not only by seasonal effects. Consequently, salt concentrations higher than those of sea water are very rare. By contrast, in the typically open Almeriensian albuferas and marshes, salt concentrations up to 4 times higher than those of sea water have been recorded.

Redondo Gómez et al. (2006, 2010), following Rubio Casal et al. (2001), found Arthrocnemum macrostachyum in the salt marshes of the Odiel and Tinto rivers, in soils with an EC between 1.6 and $85.8 \mathrm{dS} \cdot \mathrm{m}^{-1}$. Likewise, Sánchez et al. (1998), working in the marshes of the Rias of Ortigueira and Ladrido (Galicia, northwest Spain) found Halimione portulacoides, Juncus maritimus, Spartina maritima, Scirpus maritimus and Phragmites australis growing under EC conditions below $40 \mathrm{dS} \cdot \mathrm{m}^{-1}$. These EC values are similar to the records corresponding to the marshlands of the River Guadiamar, but are still well below the maximum values recorded in the Almeriensian wetlands, which often reach values close to $200 \mathrm{dS} \cdot \mathrm{m}^{-1}$.
The application of a linear model to all the data recorded in the Almeriensian wetlands has revealed the following co-relation: TDS $\left(\mathrm{g} \cdot \mathrm{L}^{-1}\right)=1.161 \mathrm{EC}\left(\mathrm{dS} \cdot \mathrm{m}^{-1}\right)$. The model shows high residues for high EC values, with the ensuing loss of predictive capability, so in order to improve the possibility of extrapolating it to other wetlands with lower saline concentrations (as in the River Guadiamar) it has been decided to calculate partial models according to the following intervals: $0<\mathrm{EC}<100 \mathrm{dS} \cdot \mathrm{m}^{-1}, 100<\mathrm{EC}<175$ $\mathrm{dS} \cdot \mathrm{m}^{-1}$ and $\mathrm{EC}>175 \mathrm{dS} \cdot \mathrm{m}^{-1}$.

With the models calculated in this manner it was made predictions of TDS and compared them with the data reserved for validation. This enabled to estimate the mean absolute error (MAE) and the root mean square error (RMSE) and to determine the accuracy of each of the models. The partial model developed for the lowest $\mathrm{EC}$ interval (Tab. 3) reduces by $45 \%$ the MAE and by $41 \%$ the RMSE as compared with the predictions made using the general model. This means a considerable increase in the global accuracy of the predictions. Similarly, in the highest EC interval the partial model reduces by $52 \%$ the MAE and by $51 \%$ the RMSE. Only in the middle interval of conductivity do both models behave in a similar way.

When reviewing scientific literature dealing with soil salinity one of the problems is the disparity of the units of measurement used. It can be often found salinity expressed as the salt content in weight divided by the unit of volume of the solution $\left(\mathrm{mg} \cdot \mathrm{L}^{-1}\right.$ or $\left.\mathrm{g} \cdot \mathrm{L}^{-1}\right)$ or by the unit of weight of soil $\left(\mathrm{mg} \cdot \mathrm{kg}^{-1}\right.$ or $\left.\mathrm{g} \cdot \mathrm{kg}^{-1}\right)$. Both units can also

Tab. 3. Mean absolute error (MAE) and root mean square error (RMSE) for the general model and for each of the partial models. $\mathrm{N}$ shows the number of samples used in the validation process

\begin{tabular}{cccccc}
\hline & \multirow{2}{*}{$\mathrm{N}$} & \multicolumn{2}{c}{ General model } & \multicolumn{2}{c}{ Partial models } \\
\cline { 3 - 6 } & & MAE & RMSE & MAE & RMSE \\
\hline $0<\mathrm{EC}<100 \mathrm{dS} \cdot \mathrm{m}^{-1}$ & 70 & 11.009 & 13.977 & 5.988 & 8.254 \\
$100<\mathrm{EC}<175 \mathrm{dS} \cdot \mathrm{m}^{-1}$ & 25 & 21.391 & 26.61 & 20.349 & 26.878 \\
$\mathrm{EC}>175 \mathrm{dS} \cdot \mathrm{m}^{-1}$ & 7 & 83.929 & 93.592 & 40.274 & 45.804 \\
\hline
\end{tabular}


26

be found expressed in terms of parts per million (ppm) or parts per thousand (ppt), either referred to weight per unit of volume $\left(\mathrm{ppm}=\mathrm{mg} \cdot \mathrm{L}^{-1} ; \mathrm{ppt}=\mathrm{g} \cdot \mathrm{L}^{-1}\right)$ or to weight per unit of weight $\left(\mathrm{ppm}=\mathrm{mg} \cdot \mathrm{kg}^{-1} ; \mathrm{ppt}=\mathrm{g} \cdot \mathrm{kg}^{-1}\right)$. Another usual form of expressing salinity records is in percentages (\%), or in percentage per thousand (\%o or ppt). This last option derives from the traditional way of expressing sea water salinity, whose interpretation is similar to those previously mentioned $(\%=\mathrm{g}$ salt $/=100 \mathrm{~mL}$ of solution; $\%$ $=\mathrm{g}$ salt $/ \mathrm{L}$ of solution). The estimation of these units of measurement requires an exhaustive analysis of the ion content of the solutions, a procedure which is both time and money-consuming. Not surprisingly, methods have been developed to estimate solution salinity by means of indirect, quicker and cheaper measurements. Probably the most widely known of these methods involves the direct estimation of the electrical conductivity of the solution as a means to determine salinity. In the International Systems of Units the unit of measurement of electrical conductivity is the siemens $(S)$, and to measure the electrical conductivity of the soil saturation extract the $\mathrm{dS} \cdot \mathrm{m}^{-1}$ record at $25^{\circ} \mathrm{C}$ is normally used. However, other units of measurement, such as $\mathrm{mS} \cdot \mathrm{cm}^{-1}, \mathrm{mmho} \cdot \mathrm{cm}^{-1}$ or $\mu \mathrm{mho} \cdot \mathrm{cm}^{-1}\left(1 \mathrm{mmho} \cdot \mathrm{cm}^{-1}\right.$ $\left.=1 \mathrm{mS} \cdot \mathrm{cm}^{-1}=1 \mathrm{dS} \cdot \mathrm{m}^{-1}\right)$, are also common practice. It can be estimate TDS $\left(\mathrm{g} \cdot \mathrm{L}^{-1}\right)$ by multiplying EC $\left(\mathrm{dS} \cdot \mathrm{m}^{-1}\right)$ by a empirically determined factor (APHA, 1992, standard method 2510) which varies from 0.55 to 0.9 . One of the most commonly used values for this factor is 0.64 (TDS $=0.64 \mathrm{EC}$ ), although this adjustment is only valid for EC $<5 \mathrm{dS} \cdot \mathrm{m}^{-1}$ (Abrol et al., 1988; USSLS 1954). The factor obtained from the samples taken in the Almeriensian wetlands for much higher EC ranges is also higher, either close to or higher than 1 (Tab. 2).
However, in highly concentrated solutions the direct measurement of the electrical conductivity does not always provide a reliable estimation of the real concentration of salts. As a result, scientific researchers of saline environments often use the practical salinity unit (psu), which originated in oceanographic studies and is defined as the ratio of the conductivity of the sample (measured at 1 atmosphere and $15^{\circ} \mathrm{C}$ ) to the conductivity of a $\mathrm{KCl}$ solution containing $32.4356 \mathrm{~g}$ of $\mathrm{KCl}$ per $\mathrm{kg}$ of solution. The sample salinity $(S)$, expressed in \%o, is estimated, according to Lewis (1980), as follows:

$$
\mathrm{S}=0.008-0.1692 \mathrm{~K}^{1 / 2}+25.3851 \mathrm{~K}+14.0941 \mathrm{~K}^{3 / 2}-
$$
$7.0261 \mathrm{~K}^{2}+2.7081 \mathrm{~K}^{5 / 2}$

where $\mathrm{K}$ represents the ratio, mentioned above, between conductivities. The previous equation is valid for the range $2 \% 0 \leq S \leq 42 \%$.

Other equations have also been published for estimating salinity values in $\%\left[\%(\mathrm{w} / \mathrm{v})=10 \cdot \mathrm{TDS}\left(\mathrm{g} \cdot \mathrm{L}^{-1}\right)\right]$ from the EC and the moisture content at saturation (Hsat) (Simón et al., 1980):

$$
\% \text { salt }(\mathrm{w} / \mathrm{v})=0.075 \cdot \mathrm{EC}\left(\mathrm{dS} \cdot \mathrm{m}^{-1}\right)+0.0261 \cdot \text { Hsat }(\%)
$$
$-1.264$

If it is apply the models of Abrol et al. (1988), APHA (1992) with a factor of 0.9, that of Simón et al. (1980) and the present general model to the data reserved for validation, it can be observe in Tab. 4 and Fig. 7, that the least reliable predictions based on the estimation of the mean absolute error (MAE) and the root mean square error (RMSE) correspond to Abrol's model and the best are ours. On the other hand, the model by Simón et al. (1980) produces negative values for $\mathrm{EC}<10 \mathrm{dS} \cdot \mathrm{m}^{-1}$.

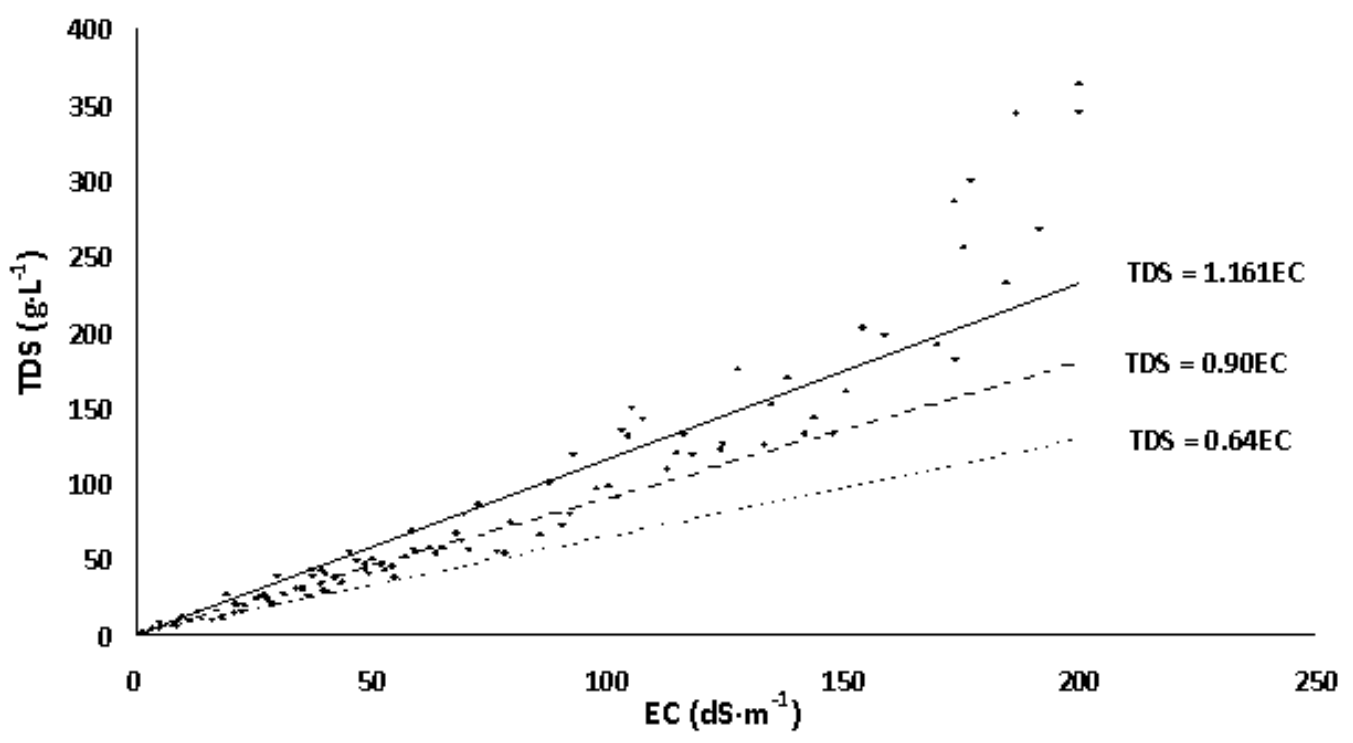

Fig. 7. EC-TDS dispersion graph of the samples used to validate the models. The lines shown in the Fig. belong to three of the four models under study, with their corresponding equations. The model by Simón et al. (1980) has not been plotted because it includes two predictive variables 
Tab. 4. Mean absolute error (MAE) and root mean square error (RMSE) for four models. $\mathrm{N}$ shows the number of samples used in the validation process

\begin{tabular}{ccccc}
\hline Models & Equation & N & MAE & RMSE \\
\hline Abrol et al. (1988) & TDS $=0.64 \cdot \mathrm{EC}$ & 102 & 37.20 & 6.17 \\
Simón et al. $(1980)$ & TDS $=0.75 \cdot \mathrm{EC}+$ & 102 & 29.75 & 5.19 \\
& $0.261 \cdot \mathrm{Hsat}-12.64$ & & & \\
APHA (1992) & TDS $=0.9 \cdot \mathrm{EC}$ & 102 & 20.72 & 4.23 \\
General model & TDS $=1.161 \cdot \mathrm{EC}$ & 102 & 18.56 & 2,98 \\
\hline
\end{tabular}

\section{Acknowledgements}

This article is part of the report of the investigation project "A study of the environmental factors determining the distribution of plant communities and species in the Mediterranean coastal wetlands of the SE of the Iberian Peninsula" P06-RNM-02286 (Call for Projects of Excellence 2006 of the Junta de Andalucía).

\section{References}

Abrol IP, Yadav JSP, Massoud FI (1988). Salt-affected soils and their management. FAO Soils Bulletin no. 39. FAO Roma.

Ahmed MZ, Khan MA (2010). Tolerance and recovery responses of playa halophytes to light, salinity and temperature stresses during seed germination. Flora 205(11):764-771.

APHA (1992). Standard methods for the examination of water and wastewater. $18^{\text {th }}$ Ed. American Public Health Association, Washington, DC.

Álvarez Rogel J, Ortiz Silla R, Alcaraz Ariza F (2001). Edaphic characterization and soil ionic composition influencing plant zonation in a semiarid Mediterranean salt marsh. Geoderma 99:81-98.

Álvarez Rogel J, Martínez Sánchez JJ, Carrasco Blázquez L, Marín Semitiel CM (2006). A conceptual model of salt marsh plant distribution in coastal dunes of southeastern Spain. Wetlands 26(3):703-717.

Álvarez Rogel J, Carrasco L, Marín CM, Martínez Sánchez JJ (2007). Soils of a dune coastal salt marsh system in relation to groundwater level, micro-topography and vegetation under a semiarid Mediterranean climate in SE Spain. Catena 69:111-121.

Amzallag GN (1994). Influence of parental $\mathrm{NaCl}$ treatment on salinity tolerance of offspring in Sorghum bicolor (L.) Moench. New Phytol 128:715-723.

Ashraf M (1994). Breeding for salinity tolerance in plants. Crit Rev Plant Sci 13:17-42.

Cant S, Kant P, Lips H, Barak S (2007). Partial substitution of $\mathrm{NO}_{3}^{-}$by $\mathrm{NH}_{4}^{+}$fertilization increases ammonium assimilating enzyme activities and reduces the deleterious effects of salinity on the growth of barely. J Plant Physiol 164:303311.

Castagna A, Donnini S, Ranieri A (2009). Adaptation to Irondeficiency requires remodelling of plant metabolism: an in- sight in chloroplast biochemistry and functionality. Chapter 21:205-212. In: Ashraf M, Ozturk M, Athar HR (Eds.). Salinity and water stress. Improving crop efficiency. Springer, Berlin.

Díaz-Maroto IJ, Vila-Lameiro P (2008). Chemical properties and macronutrients of oak soils in northwest Spain. Commun Soil Sci Plant Anal 39:1416-1435.

El Shaer HM (2009). Potential role of Sabkhas in Egypt: an overview. Chapter 23:221-228. In: Ashraf M, Ozturk M, Athar HR (Eds.). Salinity and water stress. Improving crop efficiency. Springer, Berlin.

Epstein E (1980). Responses of plants to saline environments, 7-21 p. In: Rains DW, Valentine RC, Hollaender A (Eds.) Genetic Engineering of Osmoregulation.Plenum, NY.

Hagen-Thorn A, Callesen I, Armolaitis K, Nihlgård B (2004). The impact of six European tree species on the chemistry of mineral topsoil in forest plantations of former agricultural land. For Ecol Manage 195:373-384.

Hessini K, Gandour M, Megdich W, Sotani A, Abdely C (2009). How does ammonium nutrition influence salt tolerance in Spartina alterniflora Loisel? Chapter 10:91-96. In: Ashraf M, Ozturk M, Athar HR (Eds.). Salinity and water stress. Improving crop efficiency. Springer, Berlin.

Flowers TJ (2004). Improving crop salt tolerance. J Exp Bot 55:307-319.

Greenway H, Munns R (1980). Mechanisms of salt tolerance in nonhalophytes. Annu Rev Plant Physiol 31:149-190.

Guma IR, Padrón-Mederos MA, Santos-Guerra JA, ReyesBetancort JA (2010). Effect of temperature and salinity on germination of Salsola vermiculata from Canary Islands. J Arid Environ 74:708-711.

Koyro HW, Wegmann L, Lehmann H, Lieth H (1997). Physiological mechanisms and morphological adaptation of Laguncularia racemosa to high salinity, 51-78 p. In: Lieth $\mathrm{H}$, Hamdy A, Koyro HW (Eds.). Water Management, Salinity and Pollution Control Towards Sustainable Irrigation in the Mediterranean Region: Salinity Problems and Halophyte Use. Tecnomack, Bari.

Koyro HW, Geissler N, Hussin S (2009). Survival at extreme locations: life strategies of halophytes. Chapter 17:167-177. In: Ashraf M, Ozturk M, Athar HR (Eds.). Salinity and water stress. Improving crop efficiency. Springer, Berlin.

Lewis EL (1980). The practical salinity scale 1978 and its antecedents. IEEE J Oceanic Eng OE-5(1):3-8.

Li Y (2008). Effect of salt stress on seed germination and seedling growth of three salinity plants. Pak J Biol Sci 11(9):12681272.

Lieth H (1999). Development of crops and other useful plants from halophytes, 1-18 p. In: Lieth H, Moschenko M, Lohmann M, Koyro KW, Hamdy A (Eds.). Halophytes Uses in Different Climates, Ecological and Ecophysiological Studies. Backhuys, Leiden.

Lieth U, Menzel U (1999). Halophyte Database Version 2, 159258 p. In: Lieth H, Moschenko M, Lohmann M, Koyro KW, 
28

Hamdy A (Eds.). Halophytes Uses in Different Climates, Ecological and Ecophysiological Studies. Backhuys, Leiden.

Marcum KB (1999). Salinity tolerance mechanisms of grasses in the subfamily Chloridoideae. Crop Sci 39:1153-1160.

Marañés A, Sánchez JA, de Haro S, Sánchez ST, del Moral F (1998). Análisis de suelos. Metodología e interpretación. Servicio de Publicaciones de la Univ de Almería, Spain.

Martínez-Ballesta MC, Martínez V, Carvajal M (2004). Osmotic adjustment, water relations and gas exchange in pepper plants grown under $\mathrm{NaCl}$ or $\mathrm{KCl}$. Environ Exper Bot 52:161-174.

Mateos Naranjo E, Andrades Moreno L, Redondo Gómez S (2011). Comparison of germination, growth, photosynthetic responses and metal uptake between three populations of Spartina densiflora under different soil pollution conditions. Ecotoxicol Environ Saf 74(7):2040-2049.

Orlovsky NS, Japakova UN, Shulgina I, Volis S (2011). Comparative study of seed germination and growth of Kochia prostrate and Kochia scoparia (Chenopodiaceae) under salinity. J Arid Environ 75(6):532-537.

Parida SK, Das AB (2005). Salt tolerance and salinity effects on plants. Ecotoxicol Environ Saf 60:324-349.

Pasternak D (1990). Fodder production with saline water. The Institute for Applied Research, Ben Gurion University of the Negev, 173 p. Project Report BGUN-ARI-35-90. BeerSheva, Israel.

Pujol JA, Calvo JF, Ramírez Díaz L (2000). Recovery of germination from different osmotic conditions by four halophytes from southeastern Spain. Ann Bot 85:279-286.

Redondo Gómez S, Rubio Casal AE, Castillo JM, Luque CJ, Álvarez AA, Luque T, Figueroa ME (2004). Influences of salinity and light on germination of three Sarcocornia taxa with contrasted habitats. Aquatic Bot 78:255-264.

Redondo Gómez S, Wharmby C, Castillo JM, Mateos Naranjo E, Luque CJ, de Cires A, Luque T, Davy AJ, Figueroa ME (2006). Growth and photosynthetic responses to salinity in an extreme halophyte, Sarcocornia fruticosa. Physiol Plant 128:116-124.

Redondo Gómez S, Mateos Naranjo E, Wharmby C, Luque CJ, Castillo JM, Luque T, Mohamed MF, Figueroa ME (2007). Bracteoles affect germination and seedling establishment in a Mediterranean population of Atriplex portulacoides. Aquatic Bot 86:93-96.

Redondo Gómez S, Mateos Naranjo E, Cambrollé J, Luque T, Figueroa ME, Davy AJ (2008). Carry-over of differential salt tolerance in plants grown from dimorphic seeds of Suaeda splendens. Ann Bot 102:103-112.

Redondo Gómez S, Mateos Naranjo E, Figueroa ME, Davy AJ (2010). Salt stimulation of growth and photosynthesis in an extreme halophyte, Arthrocnemum macrostachyum. Plant Biol 12(1):79-87.
Redondo Gómez S, Andrades Moreno L, Parra R, Mateos Naranjo E, Sánchez Lafuente AM (2011). Factors influencing seed germination of Cyperus capitatus, inhabiting the moving sand dunes in southern Europe. J Arid Environ 75(3):309-312.

Rivas Martínez S, Asensi A, Díez-Garretas B, Molero Mesa J, Valle F (1997). Biogeographical synthesis of Andalusia (southern Spain). J Biogeogr 24:915-928.

Rivas Martínez S, Loidi J (1999). Bioclimatology of the Iberian Peninsula. In: Rivas Martínez $S$ et al. Iter Ibericum A.D. MIM. (Excursus geobotanicus per Hispaniam et Lusitaniam, ante XLII Symposium Societatis Internationalis Scientiae Vegetationis Bilbao mense Iulio celebrandum dicti Anni). Itinera Geobot 13:41-47.

Rhoades, JD (1996). Salinity: Electrical conductivity and total dissolved solids, 417-435 p. In: Bigham JM (Ed.). Methods of soil analysis. Part 3: Chemical methods. Chapter 14. Soil Science Society of America, Inc. American Society of Agronomy, Inc. Madison. Wisconsin.

Rubio-Casal AE, Castillo JM, Luque CJ, Figueroa ME (2001). Nucleation and facilitation in salt pans in Mediterranean salt marshes. J Veg Sci 12:761-770.

Sánchez JM, Otero XL, Izco J (1998). Relationships between vegetation and environmental characteristics in a saltmarsh system on the coast of Northwest Spain. Plant Ecol 136:1-8.

Schimper AFW (1891). Pflanzengeographie auf physiologischer Grundlage. Fischer Publisher, Jena.

Simón M, Aguilar J, García A (1980). Los suelos halomorfos de la provincia de Granada III. Sales solubles y conductividad. An Edafol Agrobiol 39(1-2):121-133.

U.S. Salinity Laboratory Staff (1954). Diagnosis and improvement of Saline and Alkali Soils. Handbook 60, USDA, Washington DC, $160 \mathrm{p}$.

Vicente MJ, Conesa E, Álvarez Rogel J, Franco JA, MartínezSánchez JJ (2009). Relationships between salt type and seed germination in three plant species growing in salt marsh soils of semi-arid. Arid Land Res Manag 23(2):1532-4982.

Warne TR, Hickok LG, Sams CE, Vogelien DL (1999). Sodium/potassium selectivity and pleiotropy in stl2, a highly salt-tolerant mutation of Ceratopteris richardii. Plant Cell Environ 22:1027-1034.

Weber DJ (2009). Adaptive mechanisms of halophytes in desert regions. Chapter 18:179-185. In: Ashraf M, Ozturk M, Athar HR (Eds.). Salinity and water stress. Improving crop efficiency. Springer, Berlin.

Weber E, D’Antonio CM (1999). Germination and growth responses of hybridizing Carpobrotus species (Aizoaceae) from coastal California to soil salinity. Am J Bot 86:1257-1263.

Winter U, Kirst GO, Grabowski V, Heinemann U, Plettner I, Wiese S (1999). Salinity tolerance in Nitellopsis obtusa. Aust J Bot 47:337-346. 